\title{
Pengaruh Souvenir Olahan Susu terhadap Pendapatan Masyarakat di Kabupaten Bandung Barat
}

\author{
Euis Dasipah \\ Universitas Winaya Mukti \\ euisdasipah@yahoo.co.id \\ Reiza Miftah Wirakusuma \\ Universitas Pendidikan Indonesia \\ reizamiftah@upi.edu
}

\begin{abstract}
This research aimed to know the influence of animal feed given to cattle towards the dairy products, income, and small breeders income. The tourism being induced in this dairy products were souvenirs for tourists. Method of the survey were dairy farmers of KPSBU Member in the West Bandung Regency, through snowball sampling on 8 people with a total of 62 cattle breeders. Analysis test has been done for validity, reliability tests, and correlation analysis test and also test of track analysis. Testing on research data showed that all research variables are valid and reliable, the correlation between variables also showed a positive relationship. Path analysis produce: 1) the feed given to cattle amounted to $63.1 \%$ against dairy products affects, 2) the feed given to cattle has a positive effect against breeders income either directly or indirectly, 3) dairy products also has a positive effect against breeders income either directly or indirectly, and 4) the feed given to cattle and dairy products affect of $93 \%$ against breeders income.
\end{abstract}

Keywords_feed; milk production; income.

\section{PENDAhULUAN}

Banyak faktor yang mempengaruhi produksi susu, baik untuk konsumsi langsung atau diolah menjadi produk souvenir untuk wisatawan. Produk tersebut dibuat beragam diantaranya adalah permen susu, yoghurt, keju dan susu segar. Namun, ketika ditinjau lebih jauh, ketersediaan barang sangat terbatas dan tidak bertahan lama. Hartutik (2006) menyebutkan bahwa rendahnya produksi susu disebabkan oleh pemuliaan dan reproduksi, penyediaan dan pemberian pakan, pemeliharaan, peyediaan sarana dan prasarana, serta pencegahan penyakit dan pengobatan, dan sisanya adalah breeding dan manajemen kandang.

Keseluruhan proses dari awal hingga akhir dapat dikemas menjadi sebuah paket wisata agro yang menarik bagi siapapun. Akan tetapi, kondisi ini sangat sulit ditemukan wisatawan di Kabupaten Bandung Barat, khususnya daya tarik wisata yang berada dekat dengan KPSBU.

Selain itu menurut Firman (2010) bahwa pakan merupakan faktor produksi yang sangat penting bagi pemeliharaan sapi perah karena biaya untuk pakan bisa mencapai $60-70 \%$ dari total biaya. Sering kali terjadi peternak merugi diakibatkan oleh produktifitas sapi perah yang rendah akibat kekurangan pakan atau pemberian pakan konsentrat dan hijauannya tidak sesuai dengan kebutuhan ternak. Sudono,et al., (2003) juga menyebutkan pakan sapi perah menjadi faktor utama yang mempengaruhi produksi dan kualitas susu, serta mempengaruhi kesehatan sapi baik kesehatan tubuhnya maupun kesehatan reproduksinya.

Menurut peneliti kualitas susu di Jawa Timur yang berasal dari pemerintah Australia Barat, John Lucey (2009), bahwa salah satu faktor yang membuat produktifitas susu sapi tidak sesuai dengan yang diharapkan adalah komposisi pakan ternak dan pengelolaannya. Selanjutnya dia juga menyebutkan, melalui pengelolaan pakan yang tepat kegiatan budi daya ternak sapi perah, akan menghasilkan daging dan susu yang baik. Pada umumnya peternak memberikan pakan dengan kandungan energi yang kurang. Sehingga energi ini sebetulnya hanya untuk memenuhi kebutuhan hidup pokok ternak dan tidak mencukupi untuk menghasilkan daging dan susu berlebih.

Pada umumnya peternak belum memberikan pakan dengan perbandingan yang tepat, sehingga efisiensi pemberian pakan dalam hubungannya dengan produksi susu belum terlihat baik. Pemberian rumput pada tingkat peternak belum sesuai dengan yang seharusnya. Hal ini disebabkan oleh keterbatasan ketersedian rumput di wilayah 
Kabupaten Bandung Barat bagian Utara, sehingga untuk penyediannya para peternak melakukan ekspansi ke wilayah kabupaten lain, yaitu Subang atau Cianjur. Perbandingan pemberian hijaun dan konsentrat juga memberikan pengaruh terhadap kuntitas dan kualitas produk susu. Menurut JICA (2002) perbandingan konsentrat dengan hijauan yang menghasilkan efisiensi produksi susu yang baik yaitu sebesar 33,8\% adalah 60:40.

Kabupaten Bandung Barat memiliki berbagai pilihan daya tarik wisata untuk dikunjungi, dan tren berwisata ke destinasi ini mengalakami peningkatan, seperti pada tabel berikut ini:

TABel 1. JumlaH KunJungan Wisatawan Ke KABUPATEN BANDUNG BARAT

\begin{tabular}{llll}
\hline Tahun & \multicolumn{2}{c}{ Jumlah Kunjungan } & \multirow{2}{*}{$\begin{array}{c}\text { Total } \\
\text { Kunjungan }\end{array}$} \\
\cline { 2 - 3 } & Nusantara & $\begin{array}{l}\text { Manca- } \\
\text { negara }\end{array}$ & \\
\hline 2010 & 819.345 & 7180 & 826.525 \\
\hline 2011 & 1.065 .149 & 9334 & 1.074 .483 \\
\hline 2012 & 1.278 .179 & 10268 & 1.288 .447 \\
\hline 2013 & 1.342 .088 & 10781 & 1.352 .869 \\
\hline Sumber:
\end{tabular}

Sapi perah yang banyak di budi dayakan di Indonesia Fries Holland (FH) mampu menghasilkan air susu hingga mencapai 5892 liter perlaktasi, dengan kadar lemak 3,7 persen (Syarif dan Sumoprastowo, 1981). Namun rataan produksi susu sapi perah di Indonesia baru sekitar 10,5 liter/ekor/hari (Luthan, 2011). Dalam hubungannya antara produksi dan pendapatan Downey et al., (1989) mengungkapkan prinsip ekonomi adalah laba akan dimaksimisasi dengan produksi.

Menurut laporan Dinas Peternakan Provinsi Jawa Barat tahun 2015, dicatat bahwa perkembangan harga susu kisaran harga susu yang diterima oleh peternak di Kabupaten Bandung Barat adalah Rp 3800,00-4500,00. Namun harga susu yang diterima oleh peternak sapi perah anggota KPSBU hingga Rp 5000,00. Harga ini tergantung kualitas susu yang dihasilkan.

Tujuan penelitian ini adalah untuk mengetahui:

1. Pengaruh pakan yang diberikan pada ternak terhadap produk susu sapi perah

2. Pengaruh pakan yang diberikan pada ternak terhadap pendapatan peternak sapi perah anggota KPSBU di Kabupaten Bandung Barat.

3. Pengaruh produk susu terhadap pendapatan peternak peternak sapi perah anggota KPSBU di Kabupaten Bandung Barat.

4. Pengaruh pakan yang diberikan pada ternak dan produk susu terhadap pendapatan peternak sapi perah anggota KPSBU di Kabupaten Bandung Barat.

\section{Metode PenElitian}

\section{A. Metode yang Digunakan}

Penelitian dilaksanakan di lingkup peternakan milik peternak sapi perah anggota KPSBU di Kabupaten Bandung Barat. Data yang dikumpulkan adalah produksi dan pendapatan dari setiap ekor ternak sapi perah yang dimiliki oleh peternak. Penentuan awal jumlah sampel peternak adalah minimal 30 orang untuk 30 sapi. Penentuan sampel seperti ini berdasarkan Husein Umar (1997) dalam Sumarna Hasan (2013) yaitu penggunaan disain deskriptif dengan teknik korelasi jumlah sampel minimal 30.

KPSBU memiliki demo farm, yaitu model peternakan yang menggambarkan kondisi peternakan rakyat milik anggotanya melakukan pencatatan produksi susu harian. Jumlah peternak yang melakukan pencatatan tidak dapat mencapai jumlah/ukuran sampel yang telah ditentukan. Jumlah peternak yang diamati adalah sebanyak 8 orang, namun jumlah sapi yang dicatat produksi susunya bisa mencapai jumlah 62 ekor.

TABEL 2. OPERASIONALISASI VARIABEL

\begin{tabular}{|c|c|c|c|c|c|c|}
\hline No & Variabel & Indikator & Definisi & Parameter & $\begin{array}{c}\text { Satuan } \\
\text { dalam } \\
\text { pengukuran }\end{array}$ & $\begin{array}{c}\text { Skala } \\
\text { pengukuran }\end{array}$ \\
\hline \multirow[t]{2}{*}{1} & Pakan (X1) & $\begin{array}{l}\text { Jumlah } \\
\text { pemberian } \\
\text { pakan } \\
\text { hijauan }\end{array}$ & $\begin{array}{l}\text { Hijauan adalah berupa } \\
\text { rumput segar yang biasa } \\
\text { diberikan pada ternak } \\
\text { sapi perah }\end{array}$ & $\begin{array}{l}\text { Jumlah total rumput } \\
\text { segar yang diberikan } \\
\text { pada ternak sapi } \\
\text { perah dalam setiap } \\
\text { harinya }\end{array}$ & Kilo Gram & Rasio \\
\hline & & $\begin{array}{l}\text { Jumlah } \\
\text { pemberian } \\
\text { pakan } \\
\text { konsentrat }\end{array}$ & $\begin{array}{l}\text { Konsentrat adalah pakan } \\
\text { penguat yang kaya akan } \\
\text { sumber protein yang } \\
\text { biasa diberikan pada } \\
\text { ternak sapi perah, seperti } \\
\text { mako }\end{array}$ & $\begin{array}{l}\text { Jumlah total } \\
\text { konsentrat yang } \\
\text { diberikan pada } \\
\text { ternak sapi perah } \\
\text { dalam setiap harinya }\end{array}$ & Kilo Gram & Rasio \\
\hline 2 & $\begin{array}{l}\text { Produk } \\
\text { susu (X2) }\end{array}$ & $\begin{array}{l}\text { Produksi } \\
\text { susu harian }\end{array}$ & $\begin{array}{l}\text { Produk susu adalah } \\
\text { salah satu hasil usaha }\end{array}$ & $\begin{array}{l}\text { Jumlah produk susu } \\
\text { yang dihasilkan oleh }\end{array}$ & Liter & Rasio \\
\hline
\end{tabular}




\begin{tabular}{|c|c|c|c|c|c|c|}
\hline No & Variabel & Indikator & Definisi & Parameter & $\begin{array}{c}\text { Satuan } \\
\text { dalam } \\
\text { pengukuran }\end{array}$ & $\begin{array}{c}\text { Skala } \\
\text { pengukuran }\end{array}$ \\
\hline & & & $\begin{array}{l}\text { ternak sapi perah yang } \\
\text { berupa susu }\end{array}$ & $\begin{array}{l}\text { setiap ekor ternak } \\
\text { dalam satu periode } \\
\text { laktasi }\end{array}$ & & \\
\hline \multirow[t]{3}{*}{3} & \multirow[t]{3}{*}{$\begin{array}{l}\text { Pendapatan } \\
(\mathrm{Y})\end{array}$} & Penerimaan & $\begin{array}{l}\text { Penerimaan adalah } \\
\text { harga susu dikalikan } \\
\text { dengan jumlah produksi } \\
\text { susu }\end{array}$ & $\begin{array}{l}\text { Nilai penjualan susu } \\
\text { berdasarkan kualitas } \\
\text { susu }\end{array}$ & Rupiah & Rasio \\
\hline & & $\begin{array}{l}\text { Fix Cost } \\
\text { (biaya } \\
\text { tetap) }\end{array}$ & $\begin{array}{l}\text { Biaya tetap adalah biaya } \\
\text { yang dikeluarkan atas in } \\
\text { put (faktor produksi) } \\
\text { produksi yang } \\
\text { dikeluarkan secara tetap }\end{array}$ & $\begin{array}{l}\text { Semua biaya tetap } \\
\text { yang dikeluarkan } \\
\text { oleh peternak(biaya } \\
\text { penyusutan kandang } \\
\text { dan peralatan, sewa } \\
\text { lahan) } \\
\end{array}$ & Rupiah & Rasio \\
\hline & & $\begin{array}{l}\text { Variable } \\
\text { Cost (biaya } \\
\text { tidak tetap) }\end{array}$ & $\begin{array}{l}\text { Biaya tidak tetap adalah } \\
\text { biaya yang dikeluarkan } \\
\text { atas in put (faktor } \\
\text { produksi) produksi yang } \\
\text { dikeluarkan secara tidak } \\
\text { tetap }\end{array}$ & $\begin{array}{l}\text { Semua biaya tidak } \\
\text { tetap yang } \\
\text { dikeluarkan oleh } \\
\text { peternak (biaya } \\
\text { pakan ternak, listrik, } \\
\text { kesehatan, tenaga } \\
\text { kerja) }\end{array}$ & Rupiah & Rasio \\
\hline
\end{tabular}

B. Sumber dan Cara Penentuan Data

Sumber data berupa data primer dan sekunder. Cara pengambilan sampel pada penelitian ini menggunakan teknik non probability sampling (non random sampling). Beberapa cara yang dapat dipergunakan dalam melakukan metode non random sampling, yaitu purposive sampling, accidental sampling, quota sampling dan snowball sampling (Sumarna Hasan, 2013).

\section{Rancangan Analisis dan Uji Hipotesis}

Sumber data berupa data primer dan sekunder. Cara pengambilan sampel pada penelitian ini menggunakan teknik non probability sampling (non random sampling). Beberapa cara yang dapat dipergunakan dalam melakukan metode non random sampling, yaitu purposive sampling, accidental sampling, quota sampling dan snowball sampling (Sumarna Hasan, 2013).

1. Analisis Deskriptif Terhadap Variabel Pakan yang Diberikan Pada Ternak (X1),

Produk susu (X2), dan Pendapatan (Y)
2. Uji Analisis Korelasi dan Analisis Jalur (Path Analysis)

3. Uji Keberartian Analisi Jalur

\section{HASIl PENELITIAN DAN PEMBAhasan}

\section{A. Pembahasan Hipotesi Pertama}

Sudono,et al., (2003) menyebutkan pakan sapi perah menjadi faktor utama yang mempengaruhi produksi dan kualitas susu, serta mempengaruhi kesehatan sapi baik kesehatan tubuhnya maupun kesehatan reproduksinya. Hal tersebut dapat dibuktikan pada penelitian ini, yaitu dengan koefisien determinasi atas hubungan pakan dengan produksi susu sebesar $63,1 \%$ yang berarti bahwa pakan berpengaruh sebesar 63,1\% terhadap produksi susu sedang faktor lain yang tidak diteliti adalah sebesar 26,9\%.

Pada grafik dibawah dapat ditunjukkan hubungan pemberian pakan hijauan dan konsentrat di tempat penelitian.

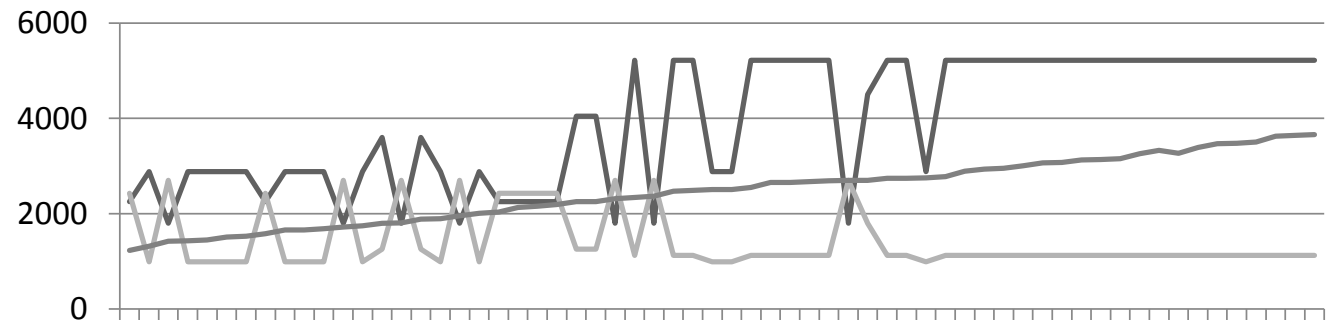

135791113151719212325272931333537394143454749515355575961

Jumlah Pemberian Hijauan (X1)

Jumlah Pemberian Konsentrat (X2)

Jumlah Produksi Susu (Q)

Gambar 1. Grafik Pemberian Hijauan dan Konsentrat terhadap Produksi Susu 
Secara umum, pakan ternak sapi perah adalah rumput dan konsentrat sebagai pakan penguat. Meskipun demikian, pemberian pakan harus sesuai dengan bobot badan sapi, kadar lemak dan produksi susunya, terutama bagi sapi-sapi yang telah berproduksi (Sudono, et al., 2003). Menurut Reksohadiprodjo, et al, (1979), hijauan makanan ternak adalah bagian dari tanaman baik berupa pucuk, daun, atau bagian atas dari tanaman yang biasa di makan oleh ternak tanpa menimbulkan gangguan fisiologis pada ternak yang mengkonsumsinya.

Peternak sapi perah anggota KPSBU telah memberikan pakan berupa hijauan dan konsentrat, namun dalam hal pemberian pakan pada umunya belum sesuai dengan kriteria kesesuaian pemberian pakan yaitu disesuaikan dengan bobot badan sapi, kadar lemak dan produksi sususnya. Pemberian pakan ditingkat peternak diperkirakan sesuai dengan kemampuan peternak tersebut memberikan pakan kepada ternaknya.

Masalah lain adalah di Kabupaten Bandung Barat sendiri ketersediaan pakan sudah mulai berkurang. Banyak faktor yang menyebabkannya, salah satunya yaitu persaingan dengan manusianya itu sendiri. Jumlah penduduk Kabupaten Bandung Barat mencapai 1.408.550 jiwa dengan kepadatan penduduk $450,42 \mathrm{jiwa} / \mathrm{km}^{2}$, sehingga banyak terjadi pengalihfungsian lahan (lapangan rumput/sumber pakan) menjadi bengunan perumahan (Profil Daerah Kabupaten Bandung Barat, 2015). Sebetulnya di Jawa Barat sendiri masih banyak lahan-lahan tidur yang belum termanfaatkan sebagai sumber pakan, namun hal ini menyangkut kebijakan masing-masing daerah.

Kisaran pemberian rumput $20 \mathrm{~kg}-58$ $\mathrm{kg} / \mathrm{ekor} / \mathrm{hari}$, pemberian mako $2 \mathrm{~kg}-20$ $\mathrm{kg}$ /ekor/hari, ampas tahu $20 \mathrm{~kg}-25$ $\mathrm{kg} / \mathrm{ekor} / \mathrm{hari}$ mampu menghasilkan produksi susu pada awal laktasi rata-rata 27 liter /ekor/hari. Syarif dan Harianto (2011) menyebutkan, pakan yang diberikan pada sapi perah pada masa produksi berupa complete feed biasanya diberikan sebanyak $8 \mathrm{~kg}$ per hari, ampas tahu -sekitar $10 \mathrm{~kg}$ per hari, dan rumput sekitar $30-35 \mathrm{~kg}$ per hari. Pada sapi perah dengan produksi susu di atas 20 liter, pemberian complete feed dan ampas tahu bisa ditambahkan.

Peternak sapi perah anggota KPSBU pada penelitian ini ada yang mengurangi pemberian hijauan, namun mereka menambah jumlah pemberian konsentrat, oleh karenanya produksi susu tetap baik. Namun hal ini mengurangi efisiensi biaya pakan. Walau bagaimana pun jika menginginkan produkstifitas yang baik dalam produksi susu pemberian pakan harus sesuai dengan kebutuhan ternak.

Perbandingan pemberian hijauan dan konsentrat yang berbeda akan menghasilkan produksi yang berbeda pula. Pada grafik di bawah dapat digambarkan bagaimana perbandingan pakan hijauan dan konsentrat yang diberikan pada ternak terhadap produksi susu pada penelitian ini.

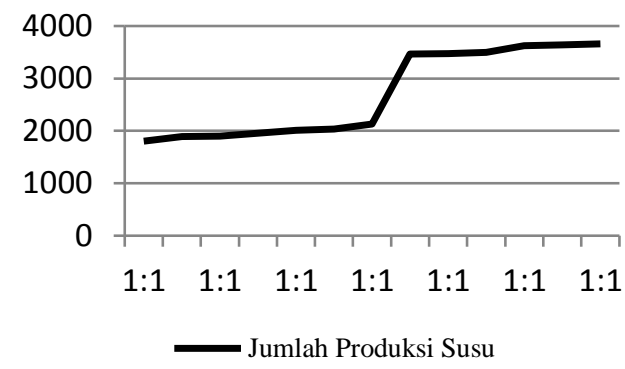

Gambar 2. Grafik yang MENGgambarkan ProduK SUSU DAN PAKAN DENGAN PERBANDINGAN HIJAUAN DAN KONSENTRAT 1:1

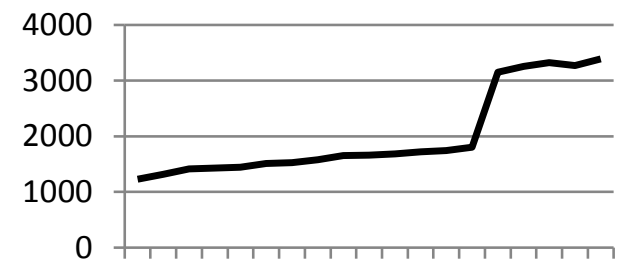

3:1 3:1 3:1 3:1 3:1 3:1 3:1 3:1 3:1 3:1

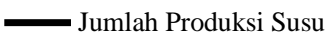

Gambar 3. GrafiK yang MengGambarkan ProduK SUSU DAN PAKAN DENGAN PERBANDINGAN HIJAUAN DAN KONSENTRAT 3:1

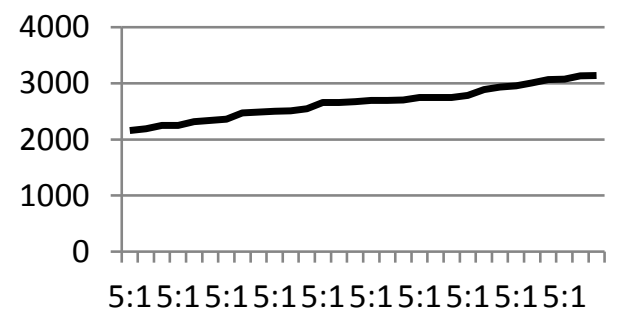

Jumlah Produksi Susu

Gambar 4. Grafik yang MengGambarkan Produksi SUSU PADA SAPI PERAH YANG DIBERIKAN PAKAN DENGAN PERBANDINGAN HIJAUAN DAN KONSENTRAT 5:1

Pada sapi perah yang diberikan perbandingan hiajuan dan konsentrat 5: 1, jumlah hijauan yang diberikan adalah 58 kg/ekor/hari dan konsentrat $12 \mathrm{~kg} / \mathrm{ekor} / \mathrm{hari}$ dengan kualitas pakan yang belum diketahui 
pada penelitian, menghasilkan produksi susu yang tinggi adalah perbandingan 5:1. Namun apabila merujuk pada tabel 17. maka, perbandingan tersebut ada pada kisaran yang tidak memungkinkan sapi berproduksi baik dari segi kuantitas. Ternak yang diteliti belum diberikan pakan dengan komposisi yang susuai dengan kebutuhan untuk mencapai hasil yang optimal.

TABEL 3 PERBANDINGAN HIJAUAN DAN KONSENTRAT DALAM BK SERTA PENGARUHNYA TERHADAP PRODUKSI SUSU

\begin{tabular}{|c|c|c|c|c|c|}
\hline \multicolumn{2}{|c|}{$\begin{array}{l}\text { Rasio hijauan dan } \\
\text { konsentrat dalam BK }\end{array}$} & \multirow[t]{2}{*}{ Kondisi Kesehatan } & \multirow[t]{2}{*}{ Produksi Susu } & \multicolumn{2}{|c|}{$\begin{array}{l}\text { Kandungan } \\
\text { pakan }\end{array}$} \\
\hline Hijauan & Konsentrat & & & TDN & Serat Kasar \\
\hline 0 & 100 & \multirow{3}{*}{$\begin{array}{l}\text { Banyak terjadi gangguan pada fungsi } \\
\text { pencernaan }\end{array}$} & \multirow[t]{3}{*}{$100 \%$ lemak turun } & $70 \%$ & $4 \%$ \\
\hline 20 & 80 & & & & \\
\hline 30 & 70 & & & $65 \%$ & $13 \%$ \\
\hline 60 & 40 & \multirow[t]{3}{*}{ Sehat } & \multirow[t]{2}{*}{ Enak } & & \\
\hline 70 & 30 & & & $58 \%$ & $22 \%$ \\
\hline 100 & 0 & & Produksi susu turun & $53 \%$ & $30 \%$ \\
\hline
\end{tabular}

Sumber: Panduan Beternak Sapi Perah, JICA (2002)

Namun konversi tingkat pemberian konsentrat terhadap produksi susu seperti ditunjukkan pada tabel 18 dapat dibuktikan melalui penelitian ini, sapi-sapi yang diberikan konsentrat pada kisaran kurang dari $20 \mathrm{~kg}$ hanya mampu menghasilkan produksi $15 \mathrm{~kg}$, begitu pun jiika konsentrat ditambah maka produksi susu pun akan naik.

Tabel 4 Prosentase Pemberian Konsentrat dan Pengaruhnya Terhadap Produksi Susu

\begin{tabular}{cccccc}
\hline \% Pemberian Konsentrat & $\begin{array}{c}\text { \%TDN pada } \\
\text { pakan }\end{array}$ & Daya serap (DM) kg & \multicolumn{2}{c}{ Produksi Susu } & Efisiensi Produksi Susu \\
\cline { 4 - 5 } & 62,3 & 16,1 & 15 & - & 25,0 \\
& 6 & 16,4 & 21,8 & 3,7 & 35,6 \\
40 & 66,1 & 14,8 & 20,8 & 3,4 & 33,8 \\
60 & 69,7 & 13,5 & 18,8 & 3,0 & 32,3 \\
80 & 73,5 & 12,4 & 14,8 & 2,6 & 26,0 \\
\hline
\end{tabular}

Sumber: Panduan Beternak Sapi Perah, JICA (2002)

Waktu pemberian pakan yang dilakukan oleh peternak pada penelitian adalah seragam, yaitu pagi dan sore dengan diberikan rumput terlebih dahulu, baru kemudian konsentrat, baru sore diberikan rumput lagi. Hal ini sesuai dengan yang dituliskan dalam JICA (2002), yaitu waktu pemberian pakan menentukan juga produktifitas sapi perah. Pemberian pakan yang baik, pada saat pagi hari diberikan hijauan terlebih dahulu untuk merangsang mikroba rumen berkerja dengan baik, selanjutnya dapat diberikan konsentrat pada siang hari, dan rumput lagi pada sore hari. Frekuansi pemberian pakan umumnya dilakukan sebanyak 1-2 kali, namun apabila diberikan pakan dengan frekuensi yang lebih banyak, maka produksi susu pun akan semakin banyak pula.

\section{B. Pembahasan Hipotesis Kedua}

Hipotesis yang kedua adalah pakan yang diberikan pada ternak berpengaruh positif terhadap pendapatan peternak sapi perah anggota KPSBU di Kabupaten Bandung Barat. Menurut Firman (2010), pakan merupakan faktor produksi yang sangat penting bagi pemeliharaan sapi perah karena biaya untuk pakan bisa mencapai $60-70 \%$ dari total biaya. Sering kali terjadi peternak merugi diakibatkan oleh produktifitas sapi perah yang rendah akibat kekurangan pakan atau pemberian pakan konsentrat dan hijauannya tidak sesuai dengan kebutuhan ternak. Biaya total untuk pakan yang dikeluarkan oleh peternak pada penelitian adalah $81 \%, 84 \%, 85 \%, 91 \%$, dan $95 \%$. Secara grafik biaya pakan dan pendapatan peternak dapat dilihat pada gambar di bawah

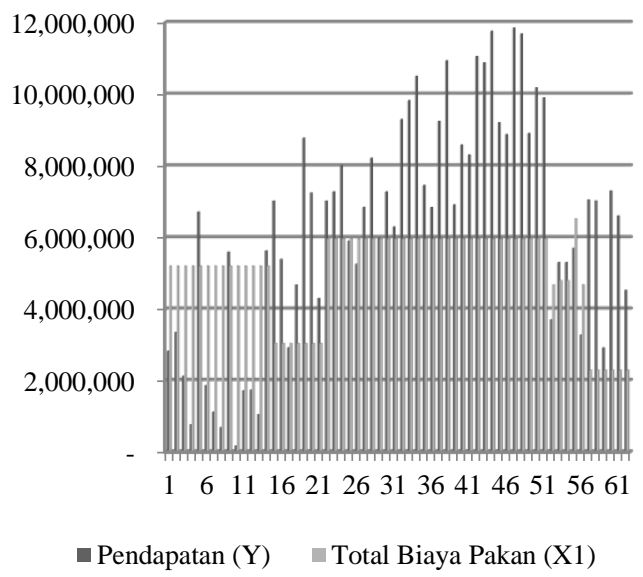

GAMBAR 5 DiAGRAM YANG MENUNJUKKAN TOTAL BIAYA PAKAN DENGAN PENDAPATAN PETERNAK

Dari hasil analisis dengan menggunakan SPPSS versi 21 memperlihatkan bahwa pakan yang diberikan pada ternak memberikan 
pengaruh secara langsung sebesar 0,0346 dan secara tidak langsung sebesar 0,1196 dengan demikian pengaruh totalnya dalah sebesar 0,1542 . Signifikansi hubungan X1 ke Y juga menunjukkan signifikan 0,000 yang lebih kecil dari $\alpha=0,05$ begitu pula dari hasil uji-t pada hasil pengujian adalah 3,279 yang lebih besar dari $\mathrm{t}_{\text {tabel }}$ pada $\alpha=0,05$ dan $\mathrm{db}=61$ adalah 1,9996. Dengan demikian dapat dibuktikan bahwa pakan yang diberikan pada ternak berpengaruh positif terhadap pendapatan peternak sapi perah anggota KPSBU baik secara langsung maupun tidak langsung (melalui X2).

\section{Pembahasan Hipotesis Ketiga}

Produksi susu yang diinginkan adalah yang memiliki kualitas dan kuantitas yang baik. Karena dengan kualitas dan kuantitas yang baik inilah pendapatan peternak akan meningkat. Produksi susu dalam bentuk harga jual adalah merupakan kualitas susu. Kualitas susu akan meningkatakan harga jual susu oleh peternak, sedangkan kuantitas akan meningkatkan pendapatan. Suatu hal yang tidak diingikan apabila terjadi kualitas susu baik, harga jual tinggi, namun produksinya sedikit atau produksi susu banyak namun kualitasnya rendah. Karena hal ini akan berakibat pada rendahnya pendapatan peternak.

Tingkat pendapatan peternak yang ditunjukkan oleh pendapatan dari setiap ekor sapi perah anggota KPSBU di Kabupaten Bandung Barat pada umumnya cukup tinggi. Nilai ini sebetulnya masih dapat dioptimalkan apabila produksi yang dihasilkan baik dalam segi kualitas dan kuantitas. Menurut Firman (2010), apabila produksi susu meningkat maka pendapatan pun akan meningkat pula.

Secara grafik produk susu dan pendapatan dapat dilihat pada gambar di bawah.

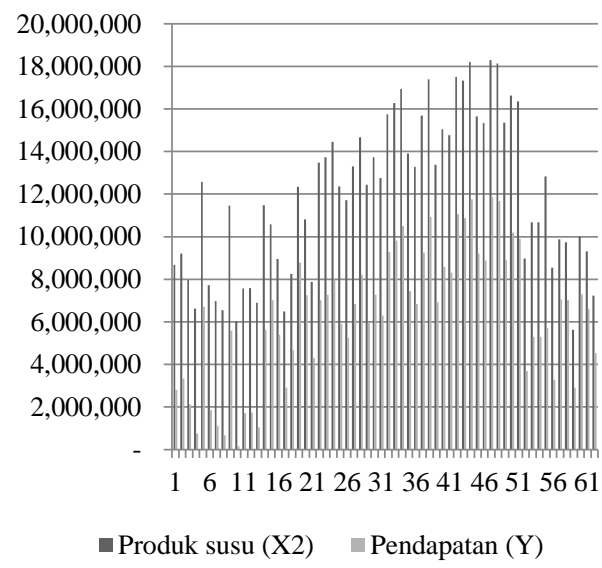

GAMBAR 6 DiAgRAM YANG MENUNJUKKAN PRODUK SUSU DAN PENDAPATAN PETERNAK
Pengujian terhadap analisis data penelitian menunjukkan pengaruh langsung dari X2 terhapad Y adalah sebesar 0,6561 dan pengaruh tidak langsung sebesar 0,1196, dan pengaruh total adalah sebesar 0,7757. Hasil analisa uji-t juga menunjukkan sigifikasi sebesar 0,000 yang lebih kecil dari $\alpha=0,05$ dengan t hitung sebesar 14,252 yang menunjukkan lebih besar dari $\mathrm{t}_{\text {tabel }}$ pada $\alpha=0,05$ dan $\mathrm{db}=61$ adalah 1,9996. Dengan demikian maka dapat dibuktikan bahwa produksusu memiliki pengaruh positif terhadap pendapatan peternak sapi perah anggota KPSBU di Kabupaten Bandung Barat, baik secara langsung maupun tidak langsung (melalui X1).

\section{Pembahasan Hipotesis Keempat}

Menurut Firman (2010) bahwa pakan merupakan faktor produksi yang sangat penting bagi pemeliharaan sapi perah karena biaya untuk pakan bisa mencapai $60-70 \%$ dari total biaya. Sering kali terjadi peternak merugi diakibatkan oleh produktifitas sapi perah yang rendah akibat kekurangan pakan atau pemberian pakan konsentrat dan hijauannya tidak sesuai dengan kebutuhan ternak. Pada penelitian ini, biaya pakan untuk setiap ekor sapi adalah pada kisaran $81 \%-92 \%$ dari total in put. Namun demikian peningkatan biaya pakan seiring dengan peningkatan produksi susu, dan apabila produksi susu meningkat maka pendapatan pun akan meningkat pula. Begitu pula pada penelitian ini terlihat pada data lampiran semakin tinggi prosentase biaya pakan menimbulkan semakin tingi produksi susu dan berakibat pada meningkatnya pendapatan.

Pemberian pakan pada ternak sapi perah dengan cara yang sesuai dengan kebutuhan akan menghasilkan susu dengan kualitas dan kuantitas yang baik. Susu dengan kualitas baik akan mendapatkan harga yang tinggi diirngi dengan kunatitas yang baik, maka pendapatan peternak pun akan meningkat.

Untuk mencapai hal ini perlu dilakukan upaya pemberian pakan ternak yang sesuai dengan kebutuhan ternak itu sendiri untuk sampai berproduksi, tidak hanya untuk mencukupi kebutuhannya hidupnya saja.

Penetapan harga susu oleh koperasi berdasarkan kandungan total solid dan TPC (kandungan bakteri dalam susu). Untuk dapat menghasilkan susu dengan harga jual tinggi ini juga dipengaruhi penanganan susu pasca pemerahan. Saringan susu adalah titik kritis pada saat penanganan pasca pemerahan (JICA, 2002). Peternak sapi perah pada penelitian melakukan penyaingan susu. Oleh karenanya 
harga jual susu peternak pada penelitian ini bisa dikatakan baik.

Dalam meningkatkan pendapatan yang ka arah yang lebih baik lagi, pemberian pakan harus lebih ditingkatkan baik dalam kualitas dan kuantitas, karena sebetulnya produksi susu yang dihasilkan oleh sapi peternak sapi perah anggota KPSBU di Bandung Barat masih dapat ditingkatkan lagi.

Data hasil penelitian antara pakan, penerimaan dari penjualan susu, dan pendapatan terdapat saling keterkaita. Secara grafik dapat ditunjukkan pada gambar di bawah.

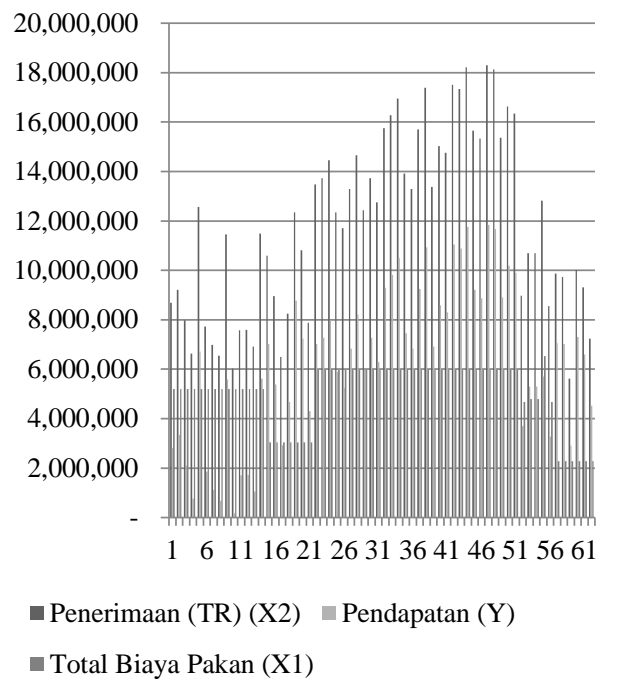

GAMBAR 7 Diagram YANG MENUNJUKKAN TOTAL BiAYA PAKAN, PENERIMAAN, DAN PENDAPATAN

Dari hasil pengujian data menggunakan program SPSS versi 20 diperoleh $\mathrm{R}^{2}$ sebesar 0,93 artinya bahwa pendapatan ditentukan oleh pakan yang diberikan pada ternak dan produk susu sebesar $93 \%$. Sedangkan $7 \%$ ditentukan oleh variabel lain yang tidak diteliti.

Setelah diuji dengan uji-t dan uji-F juga menunjukkan signifikan 0,000. Dengan demikian dapatlah dibuktikan bahwa pakan yang diberikan pada ternak dan produk susu memberikan pengaruh yang positif terhadap pendapatan peternak sapi perah anggpta KPSBU di Kabupaten Bandung Barat.

\section{KESIMPULAN DAN SARAN}

Berdasarkan hasil penelitian dapat disimpulkan, bahwa

1. Berdasarkan penelitian, pakan yang diberikan pada ternak berupa pakan hijauan dan pakan konsentrat, sebanyak dua waktu pemberian, yaitu pagi dan sore. Perbandingan pakan hijauan dan pakan konsentrat 5:1 menghasilkan efisiensi biaya pakan dan produk susu yang paling baik. Melaui analisis data dapat dibuktikan bahwa pakan yang diberikan pada ternak berpengaruh posotof terhadap produk susu.

2. Komposisi pakan hijauan dengan konsentrat yang diberikan pada ternak mempengaruhi tinggi rendahnya kuantitas produk susu yang dihasilkan di tempat penelitian. Tinggi rendahnya kuantitas produk susu ini mempengaruhi pendapatan yang diperoleh peternak. Dengan demikian pakan yang diberikan pada ternak memberikan pengaruh positif baik langsung maupun tidak langsung (melalui produk susu) terhadap pendapatan peternak sapi perah anggota KPSBU di Kabupaten Bandung Barat

3. Produk susu di peroleh dengan pemerahan yang dilakukan sebanyak dua kali sehari, yaitu pagi dan sore. Pendapatan peternak sapi perah dipengaruhi oleh kualitas dan kuantitas produk susu. Kualitas susu sapi anggota koperasi menentukan harga jual susu pada koperasi dan kuantitas menentukan besaran penerimaan untuk kemudian pendapatan. Dari data yang diperoleh membuktikan bahwa produk susu berpengaruh positif terhadap pendapatan peternak sapi perah anggota KPSBU di Kabupaten Bandung Barat baik secara langsung maupun tidak langsung (melalui pakan yang diberikan pada ternak).

4. Pariwisata dapat masuk kedalam proses pengolahan susu dari awal hingga akhir, sehingga wisatawan dapat berinteraksi langsung baik dengan sapi ternak, pengolahan susu, hingga pada pengemasan. sehingga apabila terjadi kelangkaan souvenir olahan, susu dapat diperoleh dengan membeli paket wisata.

Berdasarkan hasil pembahasan penelitian dan kesimpulan yang diperoleh, maka dapat disarankan beberapa hal sebagai berikut:

1. Kepada Dinas Pariwisata Kabupaten Bandung Barat: Memerlukan pelatihan khusus kepada para peternak agar dapat bekerja sama dengan agen perjalanan untuk membuat paket wisata agro. Penyediaan souvenir olahan susu dapat bekerja sama dengan berbagai lembaga swadaya masyarakat untuk menyimpan barang olahan di dalam rumah.

2. Kepada Pemerintah Kabupaten Bandung Barat : Seiring dengan meningkatnya kesadaran masyarakat akan pemenuhan gizi melalui susu, sapi perah sebagai potensi lokal Kabupaten Bandung Barat sudah seharusnya mendapat perhatian dari 
pemerintah dalam hal pengembangannya. Pemberdayaan lahan-lahan tidur menjadi lahan pangonan sebagai guna mengatasi keterbatasan ketersediaan pakan berupa hijauan (rumput)

3. Kepada Dinas Peternakan Kabupaten Bandung Barat : Peningkatan pengetahuan dan keterampilan penyuluh/petugas teknis lapangan terkait dengan budi daya sapi perah khususnya mengenai pakan ternak dalam kaitannya dengan produksi susu perlu terus ditingkatkan.

4. Kepada Penyuluh/Petugas Teknis lapangan : sosialisasi pakan sebagai faktor utama yang mempengaruhi produksi, sudah seharusnya mendapat perhatian penting dalam kegiatan budi daya ternak sapi perah baik dari segi kualitas dan kuantitas agar susu yang diproduksi dapat mencapai kuantitas dan kualitas yang diharapkan pula. Selain itu petugas juga membimbing dan membina peternak dalam hal pencatatan baik itu pencatatan ternaknya juga produksinya. Pencatatan produksi susu di lapangan sudah seharusnya dapat dilaksanakan dengan tertib agar dapat lebih terkontrol aspek ekonomi dari usaha peternakan sapi perah tersebut. Dengan pencatatan ini dapat dihitung pendapatan yang sebenarnya dari usaha yang dilakukan. Pencatatan terkait produksi ini juga tidak hanya sebatas produksi susu saja namun juga semua biaya yang terkait dengan produksi dengan kata lain, peternak harus sudah mulai melakukan pembukuan terhadap usaha ternaknya

5. Kepada KPSBU: Koperasi tidak menjadikan pasar susu ini monopsonistik. Koperasi harus menyediakan daya tawar yang mampu memberikan insentif yang dapat dinikmati oleh anggota. Koperasi harus dapat memaksimumkan pelayanan. Transparansi dijalankan sebagaimana mestinya, terutama mengenai harga jual susu kepada IPS, jangan sampai harga susu di tingkat peternak tidak menguntungkan peternak itu sendiri. Karena koperasi itu milik anggota, maka anggota harus memiliki pengetahuan tentang koperasi ini, merasakan keuntungan yang diperoleh dari bisnis yang dilakukan oleh koperasi. KPSBU harus menjadi koperasi yang mandiri, tidak terlibat dalam kegiatan politik apapun.

\section{DAFTAR RUJUKAN}

Downey, David dan Steven P. Erikson. (1989). Manajemen Agribisnis, Edisi kedua. Terj. Erlangga. Jakarta.

Firman, A. (2010). Agribisnis Sapi Perah. Bandung: Widya Padjadjaran.
Hartutik. (2006). Startegi manajemen Pemberian Pakan dalam Upaya Peningkatan Produktifitas Sapi Perah Rakyat melalui www.prasetya.ub.ac.id

Hasan, Sumarna. (2013). Metode Kuantitatif. Sumedang: Diktat Fakultas Pertanian Universitas Winaya Mukti.

Luthan, F. (2011). Pedoman Teknis Pengembangan Budi Daya Sapi Pola PMUK. Direktorat Budidaya Ternak. Dirjen Peternakan dan Kesehatan Hewan. 2012. Media Release (http://www.peternakan.litbang.deptan.go .id)

Pemda Kabupaten Bandung Barat. (2015). Geografis

KBB. www.bandungbaratkab.go.id.

Syarief, M.Z., dan Sumoprastowo, R.M. (1985). Ternak Perah. Jakarta: CV. Yasaguna.

Syarif, E.K. dan Harianto. (2011). Beternak dan Bisnis Sapi Perah. Jakarta: Agromedia Pustaka.

Sudono, A., Rosdiana, R.F., Setiawan, B.S. (2003). Beternak Sapi Peras secara Intensif. Jakarta: Agromedia Pustaka.

Sudono, A. (1990). Pedoman Beternak Sapi Perah. Direktorat Bina Produksi Peternakan. Direktorat Jenderal Peternakan. Departemen Pertanian. Jakarta.

Tim JICA. (2002). Buku Petunjuk Teknologi Sapi Perah di Indonesia bagi Petugas. JICA. Jakarta. 